\title{
A STUDY OF EXTERNAL PANCREATIC SECRETION IN MAN
}

\author{
By BENJAMIN KOGUT, MILTON J. MATZNER AND ALBERT E. SOBEL \\ (From the Department of Gastro-enterology and Pediatric Research Laboratory, \\ The Jewish Hospital of Brooklyn, Brooklyn)
}

(Received for publication February 17, 1936)

An opportunity to study pure pancreatic secretion in man is extremely rare. Wohlgemuth (1) reported his observations in a young man with an external pancreatic fistula. He found that the rate of secretion varied considerably with the diet, that no flow was observed with a high fat diet, that there was an increased rate of secretion with
Quantitative studies of the composition of the pancreatic fluid

While at the hospital, specimens were obtained daily from the pancreatic fistula. About $15 \mathrm{cc}$. were obtained during an interval of about 12 hours. The patient was fed various diets as indicated in Table $\mathrm{I}$.

TABLE I

Quantitative analysis of pancreatic secretion

\begin{tabular}{|c|c|c|c|c|c|c|c|c|c|c|c|c|c|c|c|c|c|c|}
\hline & & & $\mathrm{CO}_{2}$ & $\mathrm{Cl}$ & $\begin{array}{l}\text { Creat- } \\
\text { inine }\end{array}$ & $\begin{array}{l}\text { Uric } \\
\text { acid }\end{array}$ & Urea & $\begin{array}{l}\text { Non- } \\
\text { pro- } \\
\text { tein } \\
\text { nitro- } \\
\text { gen }\end{array}$ & $\begin{array}{c}\text { Total } \\
\text { nitro- } \\
\text { gen }\end{array}$ & $\begin{array}{c}\text { Total } \\
\text { pro- } \\
\text { tein * }\end{array}$ & $\begin{array}{l}\text { Cho- } \\
\text { les- } \\
\text { terol }\end{array}$ & Sugar & $\begin{array}{c}\text { Cal- } \\
\text { cium }\end{array}$ & $\begin{array}{l}\text { Phos- } \\
\text { phorus }\end{array}$ & $\begin{array}{l}\text { Po- } \\
\text { tas- } \\
\text { sium }\end{array}$ & $\begin{array}{l}\text { Total } \\
\text { base }\end{array}$ & $\begin{array}{l}\text { Phos- } \\
\text { pha- } \\
\text { tase }\end{array}$ & $\mathrm{pH}$ \\
\hline \multirow[t]{3}{*}{$\begin{array}{l}\text { C250 } \\
\text { P 75 } \\
\text { F } 75\end{array}$} & \multicolumn{2}{|c|}{$\begin{array}{l}\text { High carbo- } \\
\text { hydrate diet } \\
\text { to May } 3\end{array}\left\{\begin{array}{l}\text { April } 24 \\
\text { April } 26\end{array}\right.$} & $\begin{array}{l}\text { vol- } \\
\text { umes } \\
\text { per } \\
\text { cent }\end{array}$ & $\begin{array}{c}\text { mgm. } \\
\text { per } \\
100 \\
c c . \\
382 \\
383\end{array}$ & $\begin{array}{l}\text { Traces } \\
\text { Traces }\end{array}$ & $\begin{array}{l}\text { Traces } \\
\text { Traces }\end{array}$ & $\begin{array}{c}\text { mgm. } \\
\text { per } \\
100 \\
c c . \\
3 \\
4\end{array}$ & $\begin{array}{c}\text { mgm. } \\
\text { per } \\
100 \\
c c . \\
28 \\
40\end{array}$ & $\begin{array}{r}\text { mgm. } \\
\text { per } \\
\text { cent } \\
75 \\
137\end{array}$ & $\begin{array}{l}\text { per } \\
\text { cent } \\
0.29 \\
0.61\end{array}$ & $\begin{array}{c}\text { mgm. } \\
\text { per } \\
\text { cent } \\
\text { Neg. } \\
\text { Neg. }\end{array}$ & $\begin{array}{c}\text { mgm. } \\
\text { per } \\
100 \\
c c . \\
18 \\
15\end{array}$ & $\begin{array}{c}\text { mgm. } \\
\text { per } \\
100 \\
c c . \\
3.7 \\
4.1\end{array}$ & $\begin{array}{l}\text { mgm. } \\
\text { per } \\
100 \\
c c . \\
2.2 \\
3.2\end{array}$ & $\begin{array}{c}\text { mgm. } \\
\text { per } \\
100 \\
c c . \\
16.9 \\
21.7\end{array}$ & m.eq. & $\begin{array}{c}\text { units } \\
\text { per } \\
100 \\
c c . \\
12.7 \\
0.9\end{array}$ & 8.6 \\
\hline & $\begin{array}{l}\text { High } \\
\text { fat } \\
\text { diet }\end{array}$ & $\left\{\begin{array}{l}\text { May } 6 \ldots \ldots \\
\text { May } 7 \ldots \ldots \\
\text { May } 8 \ldots \ldots\end{array}\right.$ & & $\begin{array}{l}390 \\
385 \\
391\end{array}$ & $\begin{array}{l}\text { Traces } \\
\text { Traces } \\
\text { Traces }\end{array}$ & $\begin{array}{l}\text { Traces } \\
\text { Traces } \\
\text { Traces }\end{array}$ & $\begin{array}{l}3 \\
2 \\
3\end{array}$ & $\begin{array}{l}35 \\
33 \\
30\end{array}$ & $\begin{array}{l}70 \\
66 \\
65\end{array}$ & $\begin{array}{l}0.22 \\
0.21 \\
0.22\end{array}$ & Neg. & $\begin{array}{r}9.6 \\
12.5\end{array}$ & 3.5 & $\begin{array}{l}2.1 \\
2.2 \\
2.2\end{array}$ & $\begin{array}{l}17.4 \\
16.1\end{array}$ & $\begin{array}{r}162 \\
158 \\
170\end{array}$ & $\begin{array}{l}2.8 \\
8.8 \\
2.5\end{array}$ & \\
\hline & $\begin{array}{l}\text { Full } \\
\text { ward } \\
\text { diet }\end{array}$ & $\left\{\begin{array}{l}\text { May } 12 \ldots \ldots \\
\text { May } 13 \ldots \ldots \\
\text { May } 14 \ldots \ldots\end{array}\right.$ & $\begin{array}{c}62.0 \\
\text { Mixed } \\
80.5\end{array}$ & 380 & $\begin{array}{l}\text { Traces } \\
\text { Traces }\end{array}$ & $\begin{array}{l}\text { Traces } \\
\text { Traces }\end{array}$ & 0.5 & 39 & 59 & 0.18 & & 16.3 & 3.4 & 2.2 & 16.9 & 156 & 1.1 & 8.6 \\
\hline Blood & serum & May $13 \ldots \ldots$ & 66.0 & 355 & & & 16.0 & 30 & 1225 & 7.5 & 257 & 94 & 10.2 & 3.7 & 13.9 & 156 & 2.8 & \\
\hline
\end{tabular}

* Total protein $=6.25$ (total nitrogen-nonprotein nitrogen).

a meat diet and a continuous flow with a carbohydrate diet. Nutt (2) studied a patient with a fistula that remained open for more than a year. There was no lipolytic, moderate proteolytic, and marked diastatic activity. Deutsch and Grubel (3) reported their quantitative study of pancreatic cyst fluid. In 1932, Kahn and Klein (4) observed a patient with an external pancreatic fistula.

We recently observed a woman of 46 with a partial external pancreatic fistula, which had followed the removal of a multilocular cystadenoma of the tail of the pancreas. Quantitative chemical analyses and studies of dye excretion were carried out on the pancreatic fluid.
The results of the chemical analyses are shown in Table I. The last line represents the values found in the blood serum of the same patient.

All of the chemical determinations were carried out in duplicate. The agreement between the duplicates was well within the experimental error of the methods. The accuracy of the technique was also checked by means of known solutions. The urea values are somewhat inaccurate because of the small values found. The phosphatase was controlled by parallel determinations of bone and serum phosphatase of known activity.

\section{METHODS}

Total base was determined by the method of Van Slyke, Hiller and Berthelsen (5), and $\mathrm{CO}_{2}$ 
content according to Van Slyke and Neill (6) using the factors of Van Slyke and Sendroy (7). Chlorides were determined on $0.2 \mathrm{cc}$. of solution according to the Wilson and Ball's modification (8) of the Van Slyke (9) procedure except that 0.2 cc. of $0.15 \mathrm{~N} \mathrm{AgNO}_{3}$ was used and $0.01 \mathrm{~N}$ KCNS. Urea was determined by the method of Van Slyke and Cullen (10), and uric acid according to Benedict (11). Creatinine was estimated according to the method of Folin and Wu (12). Nonprotein nitrogen was determined by precipitating the proteins with 5 per cent trichloracetic acid performing a micro-Kjeldahl on an aliquot of filtrate. Howe's method was used for the determination of total protein (13). The Parnas and Wagner modification of Pregl's micro-Kjeldahl method was used for the final determination of nitrogen, except that the $\mathrm{NH}_{3}$ was caught in boric acid and titrated with $\mathrm{N} / 100$ sulfuric acid (14). Cholesterol was determined by Sackett's modification of Bloor's method (15), calcium by the procedure of Kramer and Tisdall (16), inorganic phosphorus by the method of Fiske and Subbarow (17), and sugar by the Kramer-Gittleman modification of the Folin-Wu method (18). $\mathrm{pH}$ was determined in a colorimetric block by the method of Henderson and Palmer (19). Phosphatase estimations were made according to the procedure outlined by Bodansky (20) except that for the final colorimetric determination of phosphate the Fiske-Subbarow method was used. For the determinations on the pancreatic juice the $\mathrm{pH}$ of the substrate was adjusted to a $\mathrm{pH}$ of 8.8. A. phosphatase unit is the amount of phosphatase which will liberate $1 \mathrm{mgm}$. of inorganic phosphorus in one hour from the buffered glycerophosphate substrate. Potassium was determined by the method of Sobel and Kramer (21).

\section{Study of dye excretion}

Our patient was injected intravenously with 5 cc. of indigo carmine on April 25, 1935, and intramuscularly on May 1, 1935, with $2 \mathrm{cc}$. of neutral red ( 2 per cent). These dyes were not perceptible in the pancreatic secretion over a period of two hours.

\section{DISCUSSION}

The relatively short period of observation did not permit drawing any broad conclusions as to alterations of composition or rate of flow under the influence of various diets. Daily total excretions could not be determined since our patient had an incomplete external fistula. It is of interest to note that there was a minimal secretion during fasting. Soon after the ingestion of food, there was an increased rate of secretion. It is also significant that the fistulous opening showed no evidence of digestion, owing to the fact that this juice was non-activated.

The results of the serum analyses are typically normal except for the potassium which is below the accepted normal value (22). The chemical analyses of the pancreatic fluid fails to reveal any definite relations to the diet. (See Table I.) The fluctuation in chloride concentrations are minor and are paralleled by a change of total base in the same direction. Both are somewhat above the normal values for blood serum. The potassium values of the fluid are within the range of normal established for serum, while the calcium values in the fluid are less than one-half of the values that are found in serum and are fairly constant. The inorganic phosphate values are also fairly constant, with one exception, and are lower than those of serum. The concentration of sugar is much lower here than in any of the other body fluids. Total protein concentrations with one exception are about the same as those found normally in spinal fluid.

The results of the nonprotein nitrogen determinations in the pancreatic fluid are at the upper end of the normal range for serum and are fairly constant. In view of this the low urea values and the almost negligible uric acid and creatinine values are surprising. The bulk of the nonprotein nitrogen must be different from that of the serum, in which urea, uric acid and creatinine constitute over 50 per cent of the total. Cholesterol is completely absent. This is usually the case for extracellular fluids in the absence of large amounts of proteins. The $\mathrm{CO}_{2}$ determinations were usually omitted because the samples were not obtained under oil. The $\mathrm{pH}$ of this fluid varied from 8.6 to 8.8. Although these specimens were not taken under oil, it is unlikely that there was an appreciable change in the hydrogen ion concentration. 
The phosphatase activity varied considerably in the various samples. The reason for this is obscure. The presence of phosphatase in the pancreatic secretion of man has not been previously reported. Umeno (23) established the presence of phosphatase in pancreatic juice recovered from experimental fistulae in dogs.

The sugar concentrations are in qualitative agreement with those of Nutt. No creatinine or uric acid values are available in the literature for comparison. The urea levels appear to corroborate the findings of J. B. Cohen (24) who observed that in animals the urea concentration of pancreatic fluid is considerably less than that of serum.

Crandall, Oldberg and Ivy (25) injected dogs intravenously with indigo carmine and neutral red. They also reported that these dyes were not recovered in the pancreatic juice. Ingraham and Visscher (26) concluded that all dyes eliminated by the dog's pancreas ionize, with their chromogen electro-negative, under proper conditions. The rapidity of closure of the pancreatic fistula did not permit us to continue further investigations of dye excretion.

\section{SUM MARY}

1. Quantitative studies of the chemical composition of external pancreatic secretion were made.

2. Injected indigo carmine and neutral red did not appear in the pancreatic secretion.

3. An increased rate of secretion was observed after the ingestion of food.

4. Non-activated pancreatic secretion did not excoriate the fistulous opening.

\section{BIBLIOGRAPHY}

1. Wohlgemuth, J., Untersuchungen über das Pankreas des Menschen. Berl. Klin. Wchnschr., 1907, 44, 47.

2. Nutt, J. B., Some observations on the chemical composition and chemical properties of a fluid derived from a pancreatic fistula. Univ. Penn. Med. Bull., 1909, 22, 196.

3. Deutsch, W., and Grubel, H., Zur Diagnose der Pankreascysten und über den inhalt einer Pankreascyste. Klin. Wchnschr., 1927, 6, 2369.

4. Kahn, J., and Klein, H. M., Human pancreatic secretion studied from a case of pancreatic cyst with fistula. Am. J. M. Sc., 1932, 184, 503.
5. Van Slyke, D. D., Hiller, A., and Berthelsen, K. C., A gasometric micro method for determination of iodates and sulfates, and its application to the estimation of total base in blood serum. J. Biol. Chem., 1927, 74, 659.

6. Van Slyke, D. D., and Neill, J. M., The determination of gases in blood and other solutions by vacuum extraction and manometric measurement. I. J. Biol. Chem., 1924, 61, 523.

7. Van Slyke, D. D., and Sendroy, J., Jr., Carbon dioxide factors for the manometric blood gas apparatus. J. Biol. Chem., 1927, 73, 127.

8. Wilson, D. W., and Ball, E. G., A study of the estimation of chloride in blood and serum. J. Biol. Chem., 1928, 79, 221.

9. Van Slyke, D. D., The determination of chlorides in blood and tissues. J. Biol. Chem., 1923, 58, 523.

10. Van Slyke, D. D., and Cullen, G. E., The determination of urea by the urease method. J. Biol. Chem., 1916, 24, 117.

11. Benedict, S. R., The determination of uric acid. J. Biol. Chem., 1922, 54, 233.

12. Folin, O., and $\mathrm{Wu}, \mathrm{H}$., $\mathrm{A}$ system of blood analysis. J. Biol. Chem., 1919, 38, 81.

13. Howe, P. E., The determination of proteins in blood - a micro method. J. Biol. Chem., 1921, 49, 109.

14. Pregl, F. (translated by Fyleman, E.), Quantitative Organic Microanalysis. P. Blakiston's Son and Co., Philadelphia, 1924, p. 99.

15. Sackett, G. E., Modification of Bloor's method for the determination of cholesterol in whole blood or blood serum. J. Biol. Chem., 1925, 64, 203.

16. Kramer, B., and Tisdall, F. F., A simple technique for the determination of calcium and magnesium in small amounts of serum. J. Biol. Chem., 1921, 47, 475.

17. Fiske, C. H., and Subbarow, Y., The colorimetric determination of phosphorus. J. Biol. Chem., 1925, $66,375$.

18. Kramer, B., and Gittleman, I. F., Technic for quantitative estimation of sugar in very small amounts of blood. J. A. M. A., 1923, 81, 1171.

19. Henderson, L. J., and Palmer, W. W., On the intensity of urinary acidity in normal and pathological conditions. J. Biol. Chem., 1913, 13, 393.

20. Bodansky, A., Phosphatase studies. II. Determination of serum phosphatase. Factors influencing the accuracy of the determination. J. Biol. Chem., 1933, 101, 93.

21. Sobel, A. E., and Kramer, B., A new colorimetric method for the quantitative estimation of small amounts of potassium. J. Biol. Chem., 1933, 100, 561.

22. Kramer, B., Inorganic constituents of the blood. Cyclopedia of Medicine, 1932, 6, 487.

23. Umeno, M., Studien über Phosphatase. VI. Über das Vorkommen der Phosphatase in der Galle und im Pankreassait. Biochem. Ztschr., 1931, 231, 346. 
24. Cohen, J. B., Uber die Verteilung des Harnstoff im menschlichen Blut und in menschlichen Sekreten. Biochem. Ztschr., 1923, 139, 516.

25. Crandall, L. A., Oldberg, E., and Ivy, A. C., IV. Contributions to the physiology of the pancreas. The elimination of dyes in the external secretion of the pancreas. Am. J. Physiol., 1929, 89, 223.

26. Ingraham, R. C., and Visscher, M. B., Studies on the elimination of dyes in the gastric and pancreatic secretions, and inferences therefrom concerning the mechanisms of secretion of acid and base. J. Gen. Physiol., 1935, 18, 695. 